\title{
Effect of macrophages on proliferation of granulosa cells in the ovary in rats
}

\author{
Y. Fukumatsu ${ }^{1,2}$, H. Katabuchi ${ }^{1}$, M. Naito ${ }^{2}$, M. Takeya ${ }^{2}$, K. Takahashi $^{2}$ \\ and H. Okamura ${ }^{1}$ \\ 'Department of Obstetrics and Gynecology; and ${ }^{2}$ Second Department of Pathology, Kumamoto \\ University Medical School, Kumamoto 860, Japan
}

\begin{abstract}
Summary. The effect of macrophages on proliferation of granulosa cells was examined in gonadotrophin-primed immature female rats. The mouse anti-rat macrophage monoclonal antibodies TRPM-2 and TRPM-3 were used and macrophages were observed in the granulosa layer and antrum of follicles and in corpora lutea and stroma around follicles. There was no difference in distribution between TRPM-2-positive cells and TRPM-3-positive cells. Macrophages with some cytoplasmic vacuoles of various sizes were also demonstrated in growing follicles. The average ratios of macrophages to granulosa cells in preantral, antral and mature follicles were $0.008,0.007$ and 0.002 , respectively. Labelling with $\left[{ }^{3} \mathrm{H}\right]$ thymidine of granulosa cells cultured with peritoneal macrophages was significantly greater and the labelling index peaked to $25.0 \%$ when the ratio of macrophages to granulosa cells was 0.01 , compared with the value of $14.2 \%$ when the granulosa cells were cultured alone. This ratio of macrophages to granulosa cells was similar to that in the preantral and antral follicles in vivo. These results suggest that macrophages participate in promoting proliferation of granulosa cells as local mediators in growing follicles.
\end{abstract}

Keywords: macrophage; granulosa cell proliferation; immunohistochemistry; culture; rat

\section{Introduction}

Proliferation and differentiation of granulosa cells in developing follicles are modulated by gonadotrophins and ovarian steroids. Paracrine and autocrine intraovarian control mechanisms of follicular development have been suggested (Hofmann et al., 1990). Epidermal growth factor and fibroblast growth factor induce the proliferation of human granulosa cells, and the former also influences progesterone production in vitro (Tapanainen et al., 1987). Macrophages enhance progesterone production in cultured granulosa cells in mice (Kirsch et al., 1981) and humans (Halme et al., 1985) and thus appear to play an important role in the control of ovarian function. However, the effect of macrophages on the proliferation of granulosa cells is unknown and the presence of macrophages in growing follicles has not been demonstrated.

The present study concerned the distribution of macrophages in the follicles at various developmental stages in gonadotrophin-primed, immature ovaries in rats in vivo and investigated the effect of macrophages on proliferation of granulosa cells in vitro.

\section{Materials and Methods}

\section{Animals}

Female Wistar rats $(40-50 \mathrm{~g}), 21$ days old, were obtained from Kyudo Co. Ltd (Kumamoto, Japan) and kept in routine laboratory conditions. Immature female rats, 22 days old, were injected subcutaneously with 10 iu pregnant 
mares' serum gonadotrophin (PMSG; Teikoku Zouki, Tokyo, Japan) at 09:00 h and $48 \mathrm{~h}$ later with $5 \mathrm{ju}$ human chorionic gonadotrophin (hCG; Mochida, Tokyo, Japan). The rats were killed by cervical dislocation and the ovaries were removed either before the gonadotrophin priming, or at 12, 24 or $48 \mathrm{~h}$ after the PMSG injection. Ovaries were also removed at 12 and $24 \mathrm{~h}$ after the hCG injection.

\section{Monoclonal antibodies}

Two mouse anti-rat macrophage monocional antibodies, TRPM-2 and TRPM-3, were produced in the Second Department of Pathology, Kumamoto University Medical School (Takeya et al., 1987, 1989). TRPM-2 reacts with most monocyte-macrophage populations and crossreacts with granulocytes (Takeya et al., 1989). TRPM-3 binds specifically to certain rat macrophage populations, but not to peripheral blood monocytes, granulocytes or lymphocytes (Takeya et al., 1987).

\section{Immunohistochemistry}

Ovaries were fixed in $2 \%$ periodate-lysine-paraformaldehyde for $6 \mathrm{~h}$ at $4 \mathrm{C}$ (McLean \& Nakane, 1974). After washing for $4 \mathrm{~h}$ in phosphate-buffered saline (PBS) containing 10,15 or $20 \%$ sucrose, they were rinsed in PBS containing $20 \%$ sucrose and $10 \%$ glycerol for $60 \mathrm{~min}$, embedded in OCT compound (Miles, Elkhart, IN, USA) and frozen in dry-ice acetone. Sections, $8 \mu \mathrm{m}$ thick, were cut in a cryostat (Bright, Huntingdon, UK) and dried in air. After inhibition of endogenous peroxidase activity (Isobe et al., 1977), the sections were incubated with each monoclonal antibody for $60 \mathrm{~min}$ at room temperature. After three washes with PBS for 5 min each, the sections were incubated for $60 \mathrm{~min}$ in peroxidase-conjugated sheep anti-mouse immunoglobulin $\left(\mathrm{F}\left(\mathrm{ab}^{\prime}\right)_{2} ; \mathrm{Amersham}\right.$, UK) diluted 1:100. Peroxidase activity was visualized by using 3,3'-diaminobenzidine (Sigma, St Louis, MO, USA) as substrate in Tris- $\mathrm{HCl}$ buffer $\left(0.05 \mathrm{moll}{ }^{\prime}, \mathrm{pH} 7.6\right)$ containing $0.01 \% \mathrm{H}_{2} \mathrm{O}_{2}$. Counterstaining was performed with methyl green.

\section{Electron microscopy}

Small pieces of fresh ovarian tissue obtained as described above were fixed in $2.5 \%$ glutaraldehyde for $2 \mathrm{~h}$ and subsequently fixed with $1 \%$ osmium tetroxide for $60 \mathrm{~min}$. After dehydration in a graded series of ethanols, they were placed in propylene oxide and embedded in epoxy resin. Ultrathin sections were cut on an Ultrotome Nova (LKB, Uppsala, Sweden), stained with lead citrate and uranyl acetate and observed in an $\mathrm{H}-300$ electron microscope (Hitachi, Tokyo, Japan).

\section{Quantitative analysis of macrophages in follicles}

Ovaries were extirpated from the rats $48 \mathrm{~h}$ after the treatment with $10 \mathrm{iu}$ PMSG, because various sizes of follicles, primary to mature, were observed in these ovaries. They were fixed and frozen as already described. Whole ovaries were cut into serial sections, $8 \mu \mathrm{m}$ thick, which were stained immunohistochemically with TRPM-3. The numbers of granulosa cells and TRPM-3-positive cells were counted in 20 specimens of each preantral, antral and mature follicle of the greatest diameter. Ratios of TRPM-3-positive cells to granulosa cells (TR3:GC) were calculated.

\section{In vivo labelling of granulosa cells with $\left.\right|^{3} \mathrm{H} \mid$ thymidine}

At $24 \mathrm{~h}$ after the treatment with $10 \mathrm{iu}$ PMSG, the rats were injected intravenously with $200 \mu \mathrm{Ci}$ [methyl${ }^{3} \mathrm{H}$ ]thymidine (New England Nuclear, Boston, MA, USA). The rats were killed and the ovaries were removed $2 \mathrm{~h}$ after the $\left[{ }^{3} \mathrm{H}\right]$ thymidine injection. The procedures of fixation to making sections were as described in the 'Immunohistochemistry' section. The specimens were dipped in liquid emulsion, Sakura NR-M2 (Konika, Tokyo, Japan) diluted 1:2 in water and exposed for 10 days. They were developed in FD-III (Yamada et al., 1990) at $20^{\circ} \mathrm{C}$ and stained with methyl green.

\section{Preparation of granulosa cells}

Granulosa cells were isolated from the follicles of the rats $24 \mathrm{~h}$ after injection with 10 iu PMSG. The ovaries were removed and dipped into PBS containing $0.02 \%$ ethylenedinitrilotetraacetic acid, pricked with a 27 -gauge needle and incubated for $8 \mathrm{~min}$ at $37^{\circ} \mathrm{C}$. Granulosa cells were isolated from the ovaries through a steel mesh by applying gentle pressure and centrifuged at $150 \mathrm{~g}$ for $5 \mathrm{~min}$ to make pellets, which were suspended in Gey's solution to destroy erythrocytes. After the second centrifugation, the pellets were suspended in RPMI-1640 (Nissui Seiyaku, Tokyo, Japan) containing $10 \%$ fetal calf serum (FCS) and incubated in $60 \mathrm{~mm}$ plastic dishes (Nunclon, Roskilde, Denmark) for $60 \mathrm{~min}$ at $37^{\circ} \mathrm{C}$ in $95 \%$ air and $5 \% \mathrm{CO}_{2}$ to eliminate macrophages. The non-adherent cells were used for culture with macrophages. Viability of the cells was $\geqslant 95 \%$, as determined by trypan blue stain. 


\section{Preparation of peritoneal macrophages}

Macrophages were collected from the peritoneal cavity of unstimulated 22-day-old female rats by peritoneal lavage.

\section{Co-culture and autoradiography with $\left.\right|^{3} \mathrm{H} \mid$ thymidine}

Granulosa cells ( $10^{5}$ per well) were dispersed in RPMI-1640 medium ( $1 \mathrm{ml}$ per well) supplemented with $10 \%$ FCS and incubated on glass chamber slides (Inter Med, Naperville, IL, USA) for $48 \mathrm{~h}$ at $37^{\circ} \mathrm{C}$ under $95 \%$ air and $5 \% \mathrm{CO}_{2}$. The cells were then cultured with macrophages in various concentrations $\left(10^{2}, 10^{3}, 10^{4}\right.$ and $10^{5}$ per well) for $24 \mathrm{~h}$ under the same conditions. To examine the proliferative capacity of the granulosa cells, they were incubated in the medium containing $1 \mu \mathrm{Ci}$ [methyl- ${ }^{3} \mathrm{H}$ ] thymidine $\mathrm{ml}^{-1}$. After incubation for $2 \mathrm{~h}$, they were fixed with $90 \%$ ethanol and dried in air. The procedures for autoradiography were as described above. They were stained with nuclear fast red. One thousand granulosa cells were examined on each chamber under a light microscope and percentages of labelled cells were calculated as the $\left[{ }^{3} \mathbf{H}\right]$ thymidine labelling index. Cells with five or more grains on the nucleus were judged to be labelled (Kato et al., 1990).

\section{Statistical analysis}

The data were presented as the mean $\pm \mathrm{SD}$. The significance of the differences between means of groups was determined by the Wilcoxon test.

\section{Results}

\section{Distribution of macrophages in the ovary}

In the ovaries of untreated immature rats, most of the follicles were primary and preantral. Follicles were developed by administration of PMSG. Antral follicles predominated at $24 \mathrm{~h}$ after the PMSG injection; every stage, primary, preantral, antral and mature, was present $48 \mathrm{~h}$ after the PMSG injection, although mature follicles were in the peripheral zone of these ovaries (Table 1). Corpora lutea were observed $24 \mathrm{~h}$ after the hCG treatment. As shown by immunohistochemistry, both TRPM-2- and TRPM-3-positive cells were observed in the granulosa layer of preantral follicles (Fig. 1a), in the granulosa layer or antrum of antral follicles (Fig. Ib) and in mature follicles (Fig. 1c), as well as in corpora lutea (Fig. 1d) and in the stroma around the follicles. These cells were round and dispersed in the follicles and round, oval or spindle-shaped in the corpora lutea and stroma. There were no differences in distribution between the TRPM-2-positive and TRPM-3-positive cells in the ovaries, or in number between the TRPM-2-positive cells and the TRPM-3-positive cells in the follicles.

Table 1. Distribution of macrophages in treated rat ovarian tissues

\begin{tabular}{|c|c|c|c|c|c|c|}
\hline & \multirow[b]{3}{*}{ Untreated } & \multirow{2}{*}{\multicolumn{3}{|c|}{$\begin{array}{l}\text { Time }(h) \text { since tre } \\
\text { Pregnant mares } \\
\text { serum gonadotrophin }\end{array}$}} & \multirow{2}{*}{\multicolumn{2}{|c|}{$\begin{array}{l}\text { ent with } \\
\text { Human chorionic } \\
\text { gonadotrophin }\end{array}$}} \\
\hline & & & & & & \\
\hline & & 12 & 24 & 48 & 12 & 24 \\
\hline \multicolumn{7}{|l|}{ Follicle } \\
\hline Primary & - & - & - & - & - & - \\
\hline Preantral & + & + & + & + & + & 0 \\
\hline Antral & $\mathrm{O}$ & + & + & + & + & 0 \\
\hline Mature & 0 & 0 & + & + & + & 0 \\
\hline Corpus luteum & 0 & 0 & 0 & 0 & 0 & + \\
\hline Stroma & + & + & + & + & + & + \\
\hline
\end{tabular}


(a)

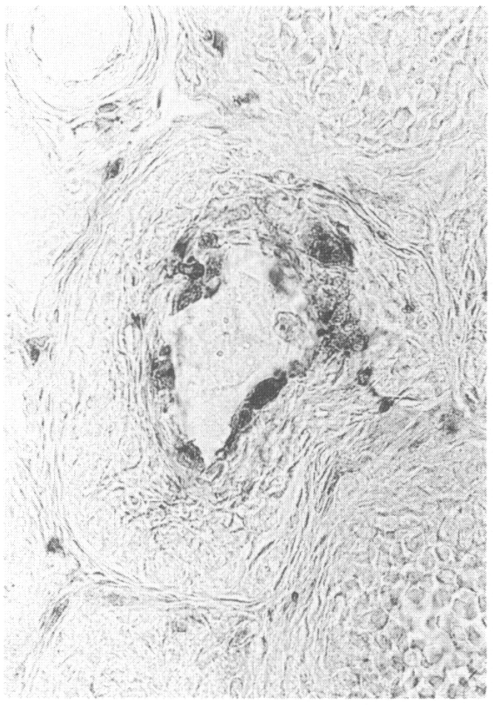

(c)

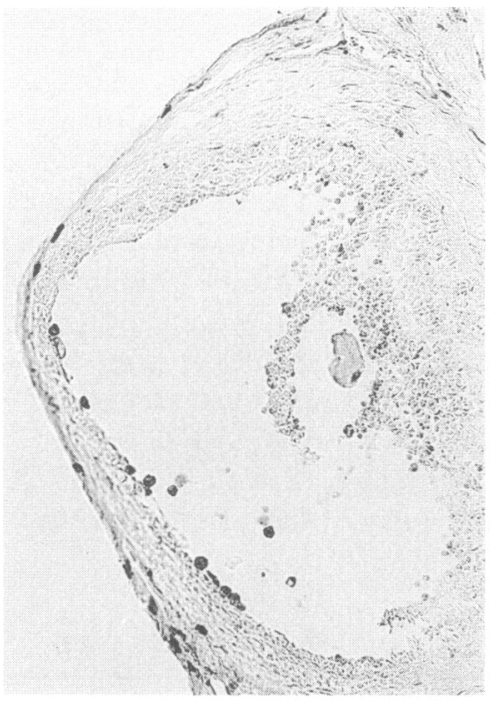

(b)

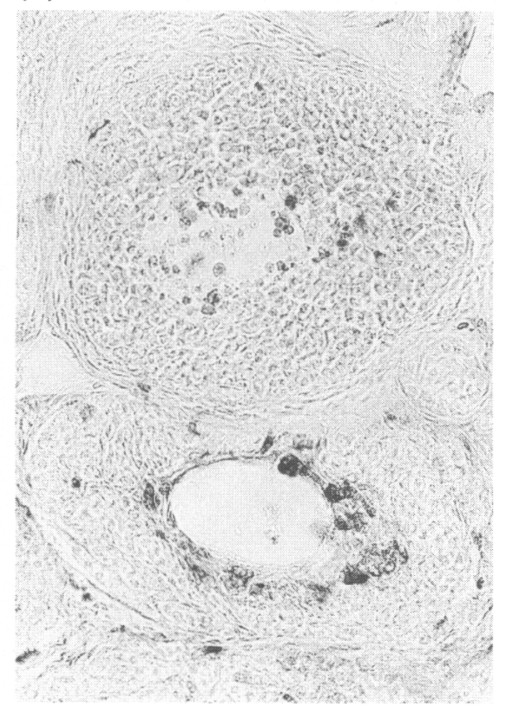

(d)

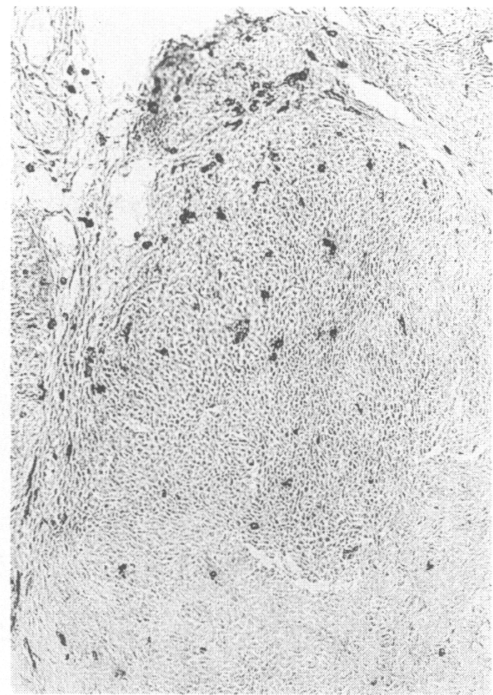

Fig. 1. Immunohistochemistry using TRPM-3 in rats: (a) preantral follicle before injection with pregnant mares' serum gonadotrophin (PMSG), $\times 320$; (b) antral follicle $24 \mathrm{~h}$ after PMSG, $\times 160$; (c) mature follicle $48 \mathrm{~h}$ after PMSG, $\times 80$; and (d) corpus luteum $24 \mathrm{~h}$ after injection with human chorionic gonadotrophin, $\times 160$. TRPM-3-positive cells are present in the granulosa layer of the preantral follicle, granulosa layer and antrum of antral and mature follicle, and in the corpus luteum and stroma.

\section{Ultrastructural features of macrophages and granulosa cells}

The ample cytoplasm of macrophages in the antrum of follicles possessed lysosomal granules, an oval or slightly indented nucleus and filopodia projecting from the cell surface (Fig. 2a, b). They were large $(20-30 \mu \mathrm{m})$ and characterized by cytoplasmic vacuoles of various sizes. The granulosa cells in these follicles had abundant ribosomes and a large nucleus, often with prominent nucleoli (Fig. 2c), suggesting that these follicles were developing. Macrophages in the corpora lutea had many lipid droplets, secondary lysosomes, or myelinoid bodies, but no cytoplasmic vacuoles 
(Fig. 3a). Macrophages in the stromal tissues did not have granules or vacuoles in the cytoplasm (Fig. 3b).

\section{Quantitative analysis of macrophages in follicles}

Ovarian follicles were classified into three stages according to the greatest diameter of follicles in serial sections: preantral $(<0 \cdot 15 \mathrm{~mm})$, antral $(0 \cdot 15-0.3 \mathrm{~mm})$ and mature follicles $(>0.3 \mathrm{~mm})$. Numbers of granulosa cells in the sections of preantral, antral and mature follicles of greatest diameter were $72 \cdot 8 \pm 50 \cdot 2,531 \cdot 1 \pm 379 \cdot 0,1547 \cdot 7 \pm 402 \cdot 8$, respectively. In 20 specimens of each stage, TRPM-3-positive cells were present in six preantral, 17 antral and 16 mature follicles. Numbers of TRPM-3-positive cells per greatest diameter section of follicle were $0.6 \pm 1.1$ in preantral, $3 \cdot 7 \pm 4 \cdot 9$ in antral, $2 \cdot 3 \pm 2 \cdot 0$ in mature follicles. The TR3:GC ratio in the growing follicles $(0.008$ in preantral, 0.007 in antral) was higher than in mature follicles $(0.002$; Table 2$)$.

\section{Proliferation of granulosa cells in vivo}

Granulosa cells in preantral and antral follicles showed strong uptake of $\left[{ }^{3} \mathrm{H}\right]$ thymidine (Fig. 4a, b). Percentages of granulosa cells labelled with $\left[{ }^{3} \mathrm{H}\right]$ thymidine were $34 \cdot 0 \pm 2 \cdot 7 \%$ in preantral follicles and $62 \cdot 6 \pm 9 \cdot 3 \%$ in antral follicles.

\section{Proliferation of granulosa cells in culture with macrophages}

Granulosa cells were dispersed in the culture medium containing $10 \%$ FCS. In culture, after adherence, they spread out on the glass chamber slides in a monolayer, showed a spindle or stellate shape and swelled markedly within $24-48 \mathrm{~h}$. It was easy to distinguish granulosa cells from peritoneal macrophages, because the latter were rounder and apparently smaller (Fig. 5). The $\left[{ }^{3} \mathrm{H}\right]$ thymidine labelling index of granulosa cells cultured with peritoneal macrophages $\left(10^{2}, 10^{3}, 10^{4}\right.$ and $\left.10^{5}\right)$ was significantly greater $(22 \cdot 3 \pm 1 \cdot 6,25 \cdot 0 \pm 2 \cdot 5,19 \cdot 5 \pm 1 \cdot 6$ and $19 \cdot 0 \pm 1.9 \%$, respectively) than that of granulosa cells cultured alone (14.2 $\pm 3.0 \%)$. The labelling index of granulosa cells peaked when the ratio of peritoneal macrophages to granulosa cells (macrophage:GC) was $0 \cdot 01$ ( $10^{5}$ for granulosa cells, $10^{3}$ for macrophages; Fig. 6 ). This ratio was similar to the TR3:GC in the preantral $(0.008)$ and antral $(0.007)$ follicles in vivo.

\section{Discussion}

Since the presence of macrophages in the granulosa layer of atretic follicles and the degenerating corpora lutea of rats was demonstrated by Bulmer (1964) using nonspecific esterase as a histochemical marker, macrophages have been thought to scavenge degenerated cells in the ovary. The present immunohistochemical and electron microscope observations showed the presence of macrophages not only in the corpora lutea but also in the growing follicles. To eliminate the atretic follicle, we used immature rats treated with PMSG and hCG and confirmed the quality of the growing follicles by observing their granulosa cells with an electron microscope. Although TRPM-2 is an anti-rat panmacrophage antibody and recognizes not only macrophages but also monocytes and granulocytes, and although TRPM-3 binds specifically to certain rat macrophage populations and does not crossreact with monocytes or granulocytes, we found no difference in distribution or number between the TRPM-2-positive cells and TRPM-3-positive cells in follicles. Thus, the number of TRPM-3-positive cells can be considered to represent the macrophage population alone, and the ratio of TRPM-3-positive cells to granulosa cells is interpreted as that of macrophages to granulosa cells in follicles. The ratio was higher in the growing follicles, such as preantral and antral follicles, than in the mature follicles (Table 2). These results suggest that macrophages in growing follicles modulate follicular development by influencing proliferation of granulosa cells, in situ. 



Fig. 2. Electron microscopy of rat antral follicle. (a,b) Macrophages observed in the antrum of follicle $24 \mathrm{~h}$ after injection with pregnant mares' serum gonadotrophin-macrophages are $20-30 \mu \mathrm{m}$ in diameter and characterized by the presence of cytoplasmic vacuoles; (c) granulosa cells in this follicle have abundant ribosomes and a high nucleus:cytoplasm ratio.
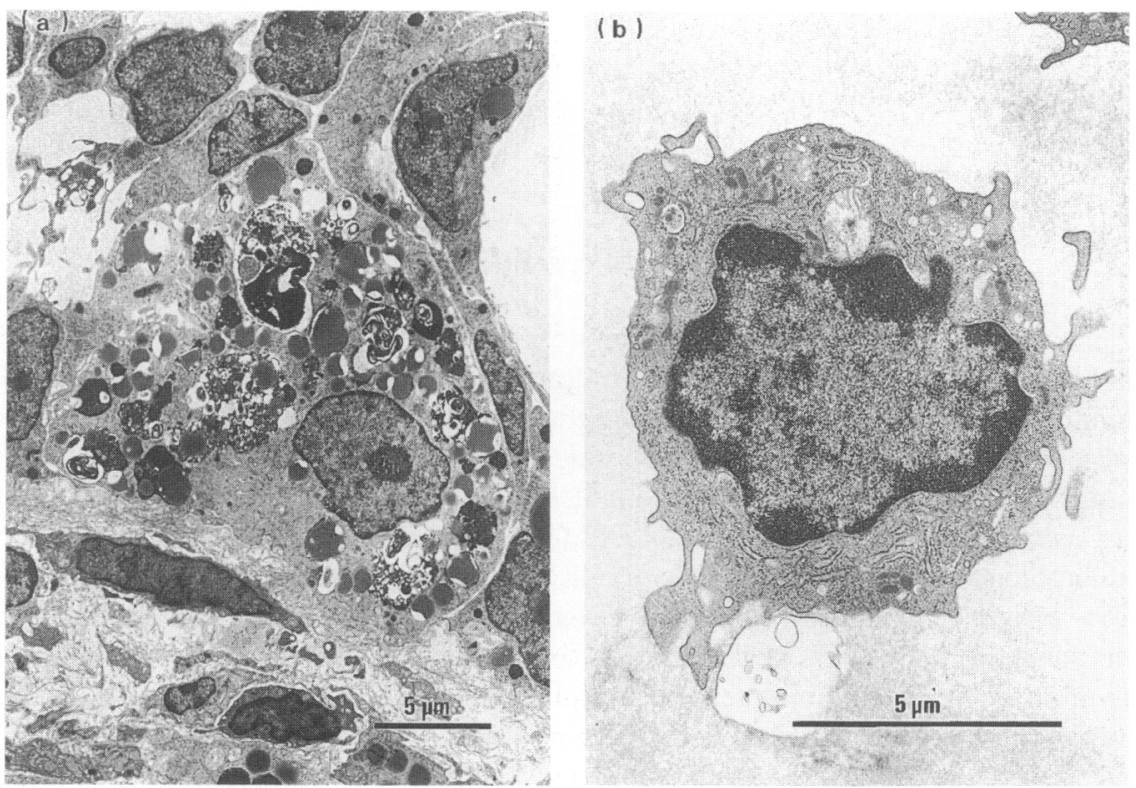

Fig. 3. Electron microscopy of macrophages in (a) the corpus luteum in rats $24 \mathrm{~h}$ after injection with human chorionic gonadotrophin - they have many lipid droplets and secondary lysosomes; and (b) the stromal tissue $24 \mathrm{~h}$ after injection with pregnant mares' serum gonadotrophin - no granules or vacuoles in the cytoplasm. 
Table 2. Quantitative analysis of granulosa cells and macrophages in rat follicles

\begin{tabular}{lccc}
\hline & Preantral & Antral & Mature \\
\hline $\begin{array}{l}\text { Diameter of largest follicle } \\
\text { section (mm) }\end{array}$ & $<0.15$ & $0 \cdot 15-0.3$ & $>0 \cdot 3$ \\
$\begin{array}{l}\text { Number of follicles examined } \\
\begin{array}{l}\text { Number of follicles in which } \\
\text { TRPM-3-positive cells were } \\
\text { present }\end{array}\end{array}$ & 20 & 20 & 20 \\
$\begin{array}{l}\text { Number of granulosa cells } \\
\text { (GC)* }\end{array}$ & $72.8 \pm 50 \cdot 2$ & $531 \cdot 1 \pm 379.0$ & $1547.7 \pm 402.8$ \\
$\begin{array}{l}\text { Number of TRPM-3-positive } \\
\text { cells (TR3)* }\end{array}$ & $0.6 \pm 1 \cdot 1$ & $3.7 \pm 4.9$ & $2.3 \pm 2.0$ \\
\begin{tabular}{l} 
TR3:GC \\
\hline
\end{tabular} & 0.008 & 0.007 & 0.002 \\
\hline
\end{tabular}

*Mean $\pm \mathrm{SD}$.

(a)

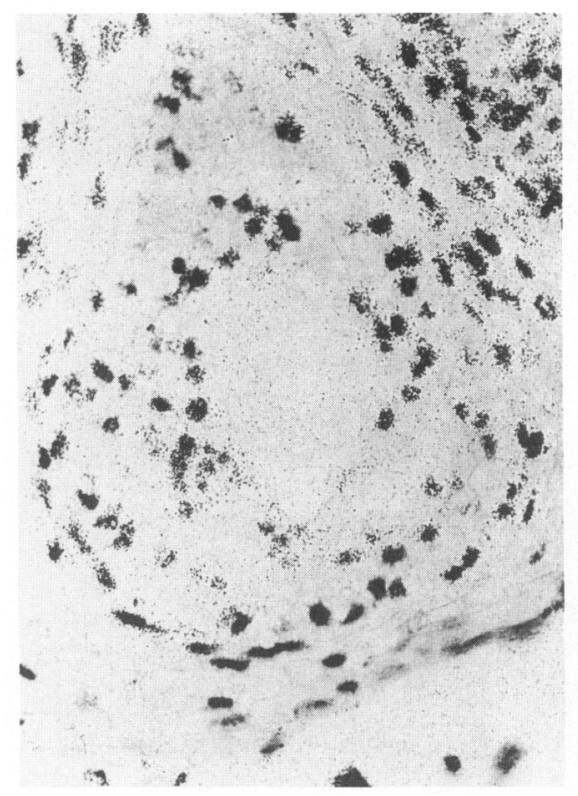

(b)

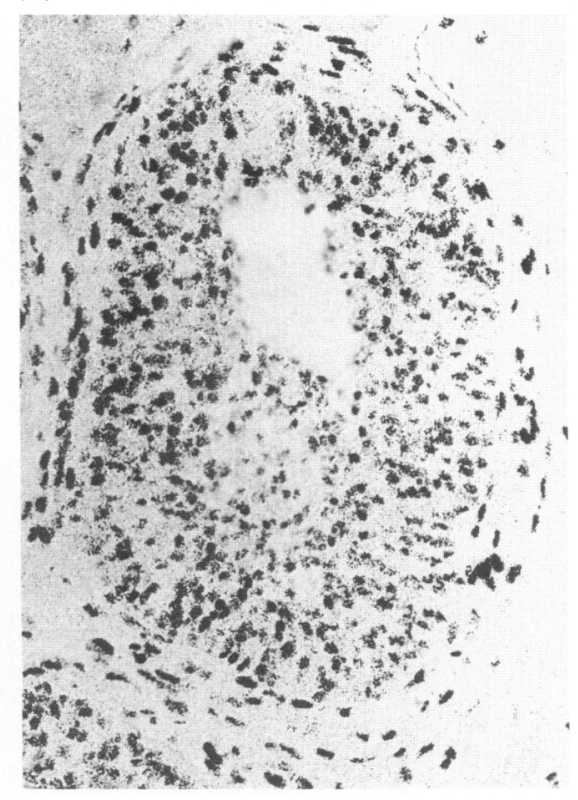

Fig. 4. Autoradiography with $\left[{ }^{3} \mathrm{H}\right]$ thymidine in vivo in rats: (a) preantral follicle, $\times 360$; and (b) antral follicle, $\times 180$.

Preantral and antral follicles predominated $24 \mathrm{~h}$ after the PMSG injection and the granulosa cells in these follicles showed a high proliferative capacity in vivo (Fig. 4). To examine the effect of macrophages on granulosa cell proliferation in vitro, we obtained granulosa cells $24 \mathrm{~h}$ after the PMSG treatment from the ovaries and cultured them with unstimulated peritoneal macrophages. The $\left[{ }^{3} \mathrm{H}\right]$ thymidine labelling index of cultured granulosa cells was significantly greater in the culture with macrophages than in the culture of granulosa cells alone. The labelling index was greatest when the ratio of macrophages to granulosa cells was 0.01 ; this value is similar to the ratio of TRPM-3-positive cells to granulosa cells in the growing follicles in vivo. These results imply that macrophages have a mitogenic effect on the granulosa cells.

The mechanism whereby macrophages promote granulosa cell proliferation remains unclear. Macrophages are known to secrete various cytokines, including interleukin 1, which stimulates 


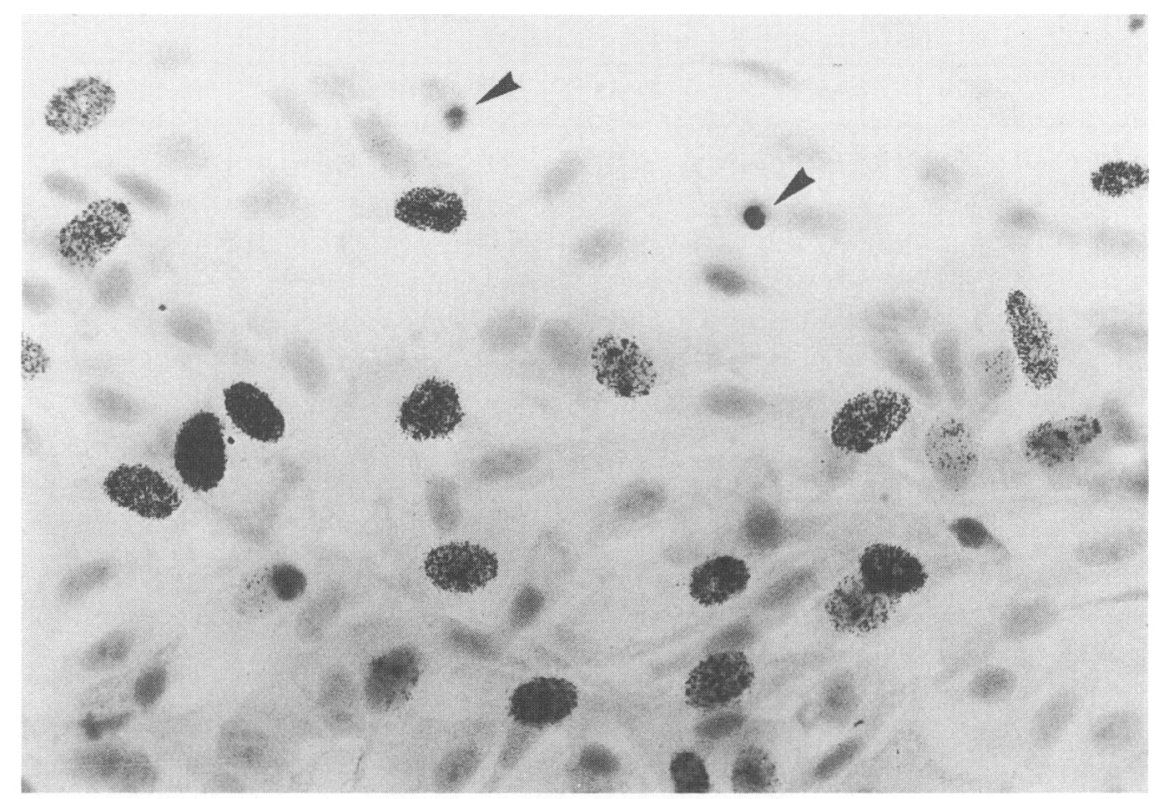

Fig. 5. $\left[{ }^{3} \mathrm{H}\right]$ thymidine autoradiography of $10^{5}$ rat granulosa cells cultured with $10^{3}$ macrophages. Macrophages (arrowheads) can be easily distinguished, because they are smaller and rounder than granulosa cells. Granulosa cells labelled with $\left[{ }^{3} \mathrm{H}\right]$ thymidine have numerous grains on the nucleus; $\times 360$.

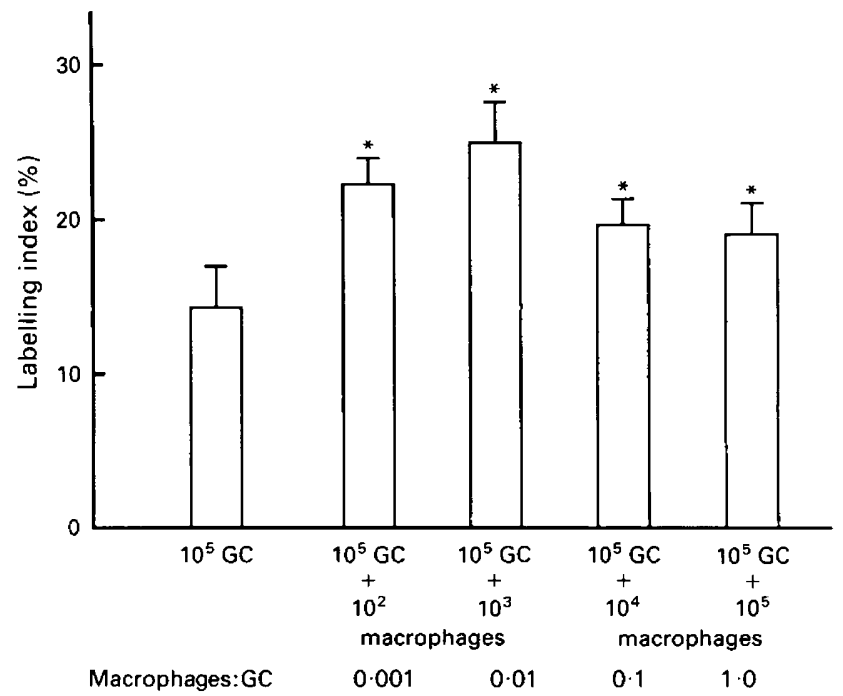

Fig. 6. $\left[{ }^{3} \mathrm{H}\right]$ thymidine labelling index of rat granulosa cells $(\mathrm{GC})$. Values are mean $\pm \mathrm{SD}$. ${ }^{*} P<0.01$ compared with control value in granulosa cells cultured alone.

granulosa cell growth (Fukuoka et al., 1989) and is present in human ovarian follicular fluid (Khan et al., 1988). Macrophages are also known to produce growth factors, such as platelet-derived growth factor (Shimokado et al., 1985), fibroblast growth factor (Baird et al., 1985), insulin-like growth factor I (Rom et al., 1988), transforming growth factors $\beta$ (Assoian et al., 1987) and $\alpha$ 
(Rappolee et al., 1988) and heparin-binding epidermal growth factor (Higashiyama et al., 1991), all of which control cell function through the paracrine or autocrine mechanisms. Of these, fibroblast growth factor and epidermal growth factor have been reported to induce granulosa cell growth (Tapanainen et al., 1987). Proliferative responses in cells are generally induced by two types of growth factor: a competence factor and a progression factor (Wharton et al., 1982). From the results of our study and those of others, it appears that macrophages may promote proliferation of granulosa cells with two or more of the factors listed above.

\section{References}

Assoian, R.K., Fleurdelys, B.E., Stevenson, H.C., Miller, P.J., Madtes, D.K., Raines, E.W., Ross, R. \& Sporn, M.B. (1987) Expression and secretion of type $\beta$ transforming growth factor by activated human macrophages. Proceedings of the National Academy of Sciences USA 84, 6020-6024.

Baird, A., Mormede, P. \& Bohlev, P. (1985) Immunoreactive fibroblast growth factor in cells of peritoneal exudate suggests its identity with macrophage-derived growth factor. Biochemical and Biophysical Research Communications 126, 358-364.

Bulmer, D. (1964) The histochemistry of ovarian macrophages in the rat. Journal of Anatomy 98, 313-319.

Fukuoka, M., Yasuda, K., Taii, S., Takakura, K. \& Mori, T. (1989) Interleukin-I stimulates growth and inhibits progesterone secretion in cultures of porcine granulosa cells. Endocrinology 124, 884-890.

Halme, J., Hammond, M.G., Syrop, C.H. \& Talbert, L.M. (1985) Peritoneal macrophages modulate human granulosa-luteal cell progesterone production. Journal of Clinical Endocrinology and Metabolism 61, 912-916.

Higashiyama, S., Abraham, J.A., Miller, J., Fiddes, J.C. \& Klagsbrun, M. (1991) A heparin-binding growth factor secreted by macrophage-like cells that is related to EGF. Science 251, 936-939.

Hofmann, G.E., Scott, R.T., Brzyski, R.G. \& Jones, H.W. (1990) Immunoreactive epidermal growth factor concentrations in follicular fluid obtained from in vitro fertilization. Fertility and Sterility 54, 303-307.

Isobe, S., Nakane, P.K. \& Brown, W.R. (1977) Studies on translocation of immunoglobulins across intestinal epithelium. 1. Improvements to study the peroxidaselabelled antibody method for application to study of human intestinal mucosa. Acta Histochemica et Cytochemica 10, 167-171.

Kato, T., Takeya, M., Takagi, K. \& Takahashi, K. (1990) Chemically induced transplantable malignant fibrous histiocytoma of the rat: analysis with immunohistochemistry, immunoelectron microscopy and $\left[{ }^{3} \mathrm{H}\right]$ thymidine autoradiography. Laboratory Investigation 62, 635-645.

Khan, S.A., Schmidt, K., Hallin, P., Di Pauli, R., De Geyter, C.H. \& Nieschlag, E. (1988) Human testis cytosol and ovarian follicular fluid contain high amounts of interleukin-1-like factor(s). Molecular and Cellular Endocrinology 58, 22 I-230.
Kirsch, T.M., Friedman, A.C., Vogel, R.L. \& Flickinger, G.L. (1981) Macrophages in corpora lutea of mice: characterization and effects on steroid secretion. Biology of Reproduction 25, 629-638.

Mclean, I.W. \& Nakane, P.K. (1974) Periodate-lysineparaformaldehyde fixative: a new fixative for immunoelectron microscopy. Journal of Histochemistry and Cytochemistry 22, 1077-1083.

Rappolee, D.A., Mark, D., Banda, M.J. \& Werb, Z. (1988) Wound macrophages express TGF $\alpha$ and other growth factors in vivo: analysis by mRNA phenotyping. Science 241, 708-711.

Rom, W.N., Basset, P., Fells, G.A., Nukiwa, T., Trapnell, B.C. \& Crystal, R.G. (1988) Alveolar macrophages release an insulin-like growth factor I-type molecule. Journal of Clinical Investigation 82, 1685-1693.

Shimokado, K., Raines, E.W., Madtes, D.K., Barrett, T.B., Benditt, E.P. \& Ross, R. (1985) A significant part of macrophage-derived growth factor consists of at least two forms of PDGF. Cell 43, 277-286.

Takeya, M., Hsiao, L. \& Takahashi, K. (1987) A new monoclonal antibody, TRPM-3, binds specifically to certain rat macrophage populations: immunohistochemical and immunoelectron microscopic analysis. Journal of Leukocyte Biology 41, 187-195.

Takeya, M., Hsiao, L., Shimokawa, Y. \& Takahashi, K. (1989) Heterogeneity of rat macrophages recognized by monoclonal antibodies: an immunohistochemical and immunoelectron microscopic study. Journal of Histochemistry and Cytochemistry 37, 635-641.

Tapanainen, J., Yamamoto, M., Leinonen, P.J., Jaffe, R.B. \& Tapanainen, P. (1987) Regulation of human granulosa-luteal cell progesterone production and proliferation by gonadotrophins and growth factors. Fertility and Sterility 48, 576-580.

Wharton, W., Gillespie, G.Y., Russell, S.W. \& Pledger, W.J. (1982) Mitogenic activity elaborated by macrophage-like cell lines acts as competence factor(s) for BALB/c 3T3 cells. Journal of Cellular Physiology 110 , 93-100.

Yamada, M., Naito, M. \& Takahashi, K. (1990) Kupffer cell proliferation and glucan-induced granuloma formation in mice depleted of blood monocytes by strontium-89. Journal of Leukocyte Biology 47, 195-205.

Received 7 August 1991 